\title{
Murilo Mendes incorpora a poesia
}

\author{
Murilo Mendes assimilates poetry
}

\section{Ulisses Infante}

Universidade Estadual Paulista - UNESP - São José do Rio Preto - São Paulo - Brasil

\begin{abstract}
Resumo: Murilo Mendes informa em textos autobiográficos que foi um cuidadoso leitor de poemas. Daí resultou o povoamento da memória por um numeroso acervo de imagens e referências, muitas das quais foram distribuídas em vários dos seus poemas. Rastrear a presença dessa matéria alheia na poesia de Murilo é um modo de captar interpretações e possibilidades de expressão percebidas no que assimilou. Também se podem captar os processos de composição poética baseados na ressignificação de imagens e unidades rítmicas incorporadas. O corpus de poemas e textos aqui abordado pretende mostrar como a incorporação - etimologicamente "junção", "enfeixamento" do alheio permitiu a Murilo Mendes, entre outras possibilidades, ponderar a figura do poeta na modernidade.
\end{abstract}

Palavras-chave: Murilo Mendes. Leitura. Memória. Mito. Modernidade.

Abstract: Murilo Mendes says in autobiographical texts that he was a careful reader of poems. Thus his memory was peopled by a large collection of images and references, many of which the poet distributed in several of his poems. Tracking the presence of this extraneous matter in the poetry of Murilo is a way of picking up his interpretations and the possibilities of expression he detected and assimilated. Also, it is possible to realize the poetical composition processes based on the embedded images and rhythmic units redefinition. The corpus of poems and texts analyzed in this paper aims to show how the incorporation - etymologically "junction", "bundling" - of other poets' matter allowed Murilo Mendes to ponder the poet's role in modernity -- among other themes.

Keywords: Metaphor. Murilo Mendes. Reading. Memory. Myth. Modernity. 


\section{Introdução}

O poeta Murilo Mendes foi também um meticuloso leitor de poesia. Evidenciam isso os textos de natureza crítica que escreveu, como os que enfeixou sob o nome de "Retratos-relâmpago", muitos dos quais são dedicados à apreciação da obra de outros poetas. A leitura atenta de seus próprios poemas, dos quais se podem desentranhar imagens e expressões remissíveis a poemas alheios, também permite perceber o cuidado com que Murilo lia outros poetas e deles incorporava imagens, dicções. Nesses percursos de ida e vinda entre textos, estabelecem-se vínculos de significação que se enraízam no acervo da memória do poeta e nos sentidos que os elementos desse acervo foram adquirindo e readquirindo ao longo da trajetória de poeta-leitor que Murilo Mendes desenvolveu. Este trabalho busca mapear parte desses percursos a partir de um conjunto de textos do próprio Murilo e de imagens e poemas alheios por ele convocados. A reflexão sobre esse material propõe que essa prática incorporativa foi frequente no trabalho poético muriliano e esteve no núcleo do desenvolvimento de alguns de seus temas principais, como a tentativa de compreensão do papel do poeta no mundo moderno tendo a reconfiguração da figura mítica de Orfeu como paradigma, incluída nessa reconfiguração a pesquisa das relações do poeta com a figura da amada morta que é também motor de poesia. Eurídice, como se verá, é musa, amada, mãe, filha, camélia, magnólia de um Orfeu cuja prática entretece o pessoal e o público.

\section{Um texto}

O poema "Despedida de Orfeu", do livro Parábola, escrito entre 1946 e 1952 e publicado em 1959, no conjunto das Poesias (1925 - 1955), de Murilo Mendes, é o ponto de partida deste trabalho. Encontram-se nele imagens e sintagmas que remetem a Heráclito de Éfeso, a Platão, a Virgílio, a Ovídio, às Argonáuticas, a Sá de Miranda, Camões, Calderón de la Barca, Raimundo Correia, Alphonsus de Guimarães, Castro Alves, Nerval, Baudelaire entre outros. Nem todos serão abordados neste trabalho, devido às limitações de extensão; acredita-se, no entanto, que o conjunto aqui apresentado seja suficiente para demonstrar um modus operandi muriliano no que diz respeito à memória de leitura como fonte do trabalho poético.

Eis o poema, como aparece nas edições de 1959 e de 1994:

\section{Despedida de Orfeu}

É hora de vos deixar, marcos da terra,

Formas vãs do mudável pensamento,

Formas organizadas pelo sonho:

Cantando, vossa finalidade apontei.

É hora de vos deixar, poderes do mundo,

Magnólias da manhã, solene túnica das árvores,

Montanhas de lonjura e peso eterno,

Pássaros dissonantes, castigado sexo,

Terreno vago das estrelas;

Jovem morta que me deste a vida,

Proas de galeras do céu, demônios lúcidos,

Longo silêncio de losangos frios,

Pedras de rigor, penumbras d'água,

Deuses de inesgotável sentido,

Bacantes que destruís o que vos dei;

É hora de vos deixar, suaves afetos,

Magia dos companheiros perenes,

Subterrâneos do clavicórdio, veludações do clarinete,

E vós, forças da terra vindas,

Admiráveis feras de cetim e coxas;

Claro riso de amoras, odor de papoulas cinerárias,

Arquiteturas do mal, poços de angústia,

Modulações da nuvem, inúmeras matérias

Pela beleza crismadas:

Cantando, vossa finalidade mostrei.

É hora de vos deixar, sombra de Eurídice,

- Constelação frouxa da minha insônia -,

Lira que aplacaste o uivo do inferno.

É hora de vos deixar, golfo de lua,

Orquestração da terra, álcoois do mundo,

Morte, longo texto de mil metáforas 
Que se lê pelo direito e pelo avesso,

Minha morte, casulo que desde o princípio

habito;

É hora de explodir, largar o molde:

Cumprindo o rito antigo,

Volto ao céu original,

Céu debruado de Eurídice;

Homem, cripto-vivente,

Sonho sonhado pela vida vã,

Cantando expiro. (MENDES, 1994, p. 552 553)

Os versos de métrica variada criam um texto de tom grave. É do arquipoeta Orfeu a voz que se dirige aos entes nomeados. E a dimensão de quem lança sua fala no poema é amplificada por se estar à morte, passagem ou limite, metro definitivo e rigoroso de tudo o que a existência elaborou. No caso de Orfeu, tendese a imaginar a cena violenta em que o poeta é atacado e despedaçado pelas mênades; o texto, no entanto, resolve-se em calma e comedimento.

"Despedida de Orfeu" estabelece nexos evidentes com os textos de Virgílio e Ovídio que narram o mito de Orfeu e com as várias Argonáuticas. Orfeu é, neste caso, uma voz da memória literária que se perscruta em busca de origens remotas. Argo "galera do céu", nau convertida em constelação por Zeus - teria realizado a primeira grande travessia náutica da história humana: Orfeu participou dela, e as diferentes tradições o fazem ritmar o remar e o dançar de seus companheiros, cantar a origem do cosmos e dos deuses, contracantar o canto de morte das sereias, adormecer o monstro que velava o velocino, aplacar montanhas de lonjura e peso eterno que finalmente se enraízam na terra e franqueiam aos homens a passagem. Orfeu argonauta é também remissão ao puro encantamento narrativo - o amor às belas histórias, o deixar-se enlear pelas façanhas que inebriam o espírito e ao mesmo tempo expõem ao homem o que o homem faz e planeia fazer. Orfeu também desceu ao Hades e lá seu canto prodigioso subjugou horrores - Virgílio e Ovídio o narram. Não trouxe de volta a amada, mas isso talvez se tenha devido a um saber, não a um fracasso. Domesticou feras e pastoreou árvores, civilizou os homens, fez da natureza um dia hostil companheira afável, pois interpretou suas falas e fez-se compreender por ela. Contou histórias de amantes infelizes, homens e mulheres que se transformaram em outros seres que, numa irresolução trágica, continuam a ser quem eram mesmo depois de o deixar de ser - considere-se que, nas Metamorfoses ovidianas, ele assume a voz e narra vários mitos metamórficos. Esse entrelaçar de Orfeus do mundo antigo se verifica no poema de Murilo Mendes por meio daquilo que é talvez o núcleo mesmo de todo fazer poético: imagens e imagens feitas verbo, que se encadeiam e desdobram em outras imagens de outros textos próprios e alheios. E desse mundo original, no qual seu papel era claro e venerando, Orfeu foi buscado pela modernidade:

Certo è invece che il tracio Orfeo nella coscienza generale dei Greci, e più tardi anche dei Romani, era innanzitutto e soprattutto un cantore assolutamente straordinario, un simbolo per il fascino del canto e in generale della "musica" - nel senso antico, comprensivo anche della poesia - che è capace persino de scongiurare le tenebrose forze della morte. E come simbolo di ciò Orfeo è a tutt'oggi vivo. (RIEDWED, 1996, p. 1280)

\section{Outros textos}

A "Despedida de Orfeu" aponta para além dos textos do mundo antigo. Eis um poema de Sá de Miranda que se entrelê nos versos murilianos:

O sol é grande, caem co'a calma as aves, do tempo em tal sazão, que soe ser fria; esta água que d'alto cai acordar-m'-ia do sono não, mas de cuidados graves.

Ó cousas, todas vãs, todas mudaves, que é tal coração qu'em vós confia? Passam os tempos, vai dia trás dia, incertos muito mais que ao vento as naves.

Eu vira já aqui sombras, vira flores, vi tantas águas, vi tanta verdura, as aves todas cantavam d'amores. 
Tudo é seco e mudo; e, de mestura, também mudando-m'eu fiz doutras cores: e tudo o mais renova, isto é sem cura! (MIRANDA, 1942, v. 1, p. 318)

Neste texto em particular, o ritmo grave dos versos desenvolve um topos clássico: a consciência da incessante passagem do tempo. O sujeito lírico inicialmente desenha uma paisagem suave, na qual insere a si mesmo como receptor de sensações: a água que cai - figuração da passagem do tempo - o acordaria, mas não do sono, e sim de "cuidados graves" - a consciência da constante mudança e da transitoriedade das coisas, e o equívoco que é confiar naquilo cuja condição é a mudança ininterrupta. Nos dois tercetos, estabelece-se o contraste entre um passado farto de sensações e sons e um presente "seco e mudo". Também o sujeito lírico se faz outro com a passagem do tempo: assim flui a existência e o que resta é ponderá-la e incorporá-la ao patrimônio da reflexão humana.

"Formas vãs do mudável pensamento" diz o decassílabo muriliano, relendo e reavivando o decassílabo mirandino "Ó cousas, todas vãs, todas mudaves". Sá de Miranda localiza a mudança e a vanidade nas "cousas", fazendo concreta a noção que Murilo expressa mais abstratamente ao falar em "formas" e "pensamento". Água e sombra são outros elementos notáveis do texto de Sá de Miranda, e parecem reapresentar-se no texto muriliano na imagem misteriosamente melancólica das "penumbras d'água".

Murilo incorpora ao elenco de imagens de "Despedida de Orfeu" a dicção buscada ao classicismo português. Reelabora e preserva essa língua que Sá de Miranda experimentava em novas formas que Camões viria a trabalhar em profundidade. Ambos ressurgem na fala do Orfeu muriliano também no que ela incorpora da dicção que ajudaram a desenvolver e fixar. Fazem-se ouvir dessa dicção, injetada no texto como imagem acústica integrada ao conjunto mnemônico, pois sua dimensão sonora se integra à da memória de poesia de cada leitor:

O elemento métrico-musical, antes de mais nada, mostra o verso como lugar de uma memória e de uma repetição. (...) Através do elemento musical, a palavra poética comemora então o seu próprio inacessível lugar originário e diz a indizibilidade do evento de linguagem (encontra [trova\}, pois, o inencontrável [introvabile]. (AGAMBEN, 2006, p. 107).

Também ressoam na "Despedida de Orfeu" versos como os da fala de Segismundo, na Cena XIX da Segunda Jornada de La vida es sueño:
Y sí haremos, pues estamos
en mundo tan singular,
que el vivir sólo es soñar;
y la experiencia me enseña
que el hombre que vive sueña
lo que es hasta despertar. (...)
¿Qué es la vida? Un frenesí.
¿Qué es la vida? Una ilusión,
una sombra, una ficción,
y el mayor bien es pequeño;
que toda la vida es sueño,
y los sueños, sueños son.
(BARCA, 1998, p. 164)

"El vivir sólo es soñar", "que toda la vida es sueño,/ y los sueños sueños son." são versos e imagens que remetem diretamente a versos e imagens da "Despedida": "Formas organizadas pelo sonho", "Homem, cripto-vivente, / Sonho sonhado pela vida vã." Esse tema, que remonta pelo menos a Píndaro diz a VIII Pítica: "Efêmeros! Que somos nós? Que não somos? Sombra de sonho é o homem!" (PEREIRA, 2003, p. 205) - propiciaria uma excursão riquíssima por textos cuja temática são as relações entre sonho e realidade, morte e vida, morte em vida. $\mathrm{O}$ fato de que se trata de "formas organizadas pelo sonho" não as invalida como possibilidades de investigar a realidade; pode, ao contrário, conferir-Ihes outra estatura nessa investigação, como propõe Pascal:

Além de que ninguém tem segurança - fora da fé - se está acordado ou dormindo, visto que durante o sono acredita-se estar acordado com tanta firmeza como quando o fazemos. Como muitas vezes se sonha que se está sonhando, sobrepondo um sonho a outro. Não pode acontecer que esta metade da vida seja ela própria apenas um sonho, sobre o qual os outros são enxertados, e de que acordamos no momento da morte, durante a qual temos tão pouco os princípios da verdade e do bem quanto durante o sono natural? Todo esse 
escoar-se do tempo, da vida, e esses diversos corpos que sentimos, esses diferentes pensamentos que nos agitam não são talvez mais do que ilusões semelhantes ao escoar-se do tempo e aos vãos fantasmas de nossos sonhos. Acredita-se ver os espaços, as figuras, os movimentos, sente-se e mede-se o escoar do tempo, e finalmente age-se da mesma forma que quando se está acordado. De modo que, como a metade da vida se passa em sono, por nossa própria confissão ou o que quer que nos pareça não temos nenhuma ideia da verdade, sendo então ilusões todos os nossos sentimentos. Quem sabe se essa outra metade da vida em que pensamos estar acordados não é outro sono um pouco diferente do primeiro. (PASCAL, 2005, p. 44-45)

A incapacidade de traçar limites precisos entre o que se vive na vigília e o que se vive no sonho instaura entre esses estados um continuum para 0 exercício da inteligência humana da realidade. Buscar compreender o fluxo do tempo e da vida e as relações que se estabelecem com o mundo circundante "não são talvez mais do que ilusões semelhantes ao escoarse do tempo e aos vãos fantasmas de nossos sonhos": Pascal projeta sobre a experiência da vigília o fluir imagético do sonho, e as formas cambiantes que circundam as consciências humanas assomam como que organizadas por um imaginário de natureza semelhante ao que organiza as formas oníricas. É a isso que remetem os versos de Murilo: as "formas" provêm de uma mesma matriz, o imaginário humano, a cuja constituição a matéria onírica oferece farta contribuição. O homem é "sonho sonhado pela vida vã": sonho sobreposto a sonho, diz Pascal. No momento em que rompe o silêncio e passa a anunciar sua despedida, Orfeu convoca primeiramente os "marcos da terra" e explicita a matéria de que são feitos: formas sujeitas à mudança, condensações de pensamento e sonho, cristalizações do esforço humano por obter alguma fixação no que é fluido.

Outro texto incorporado à "Despedida de Orfeu" é o "Plenilúnio", de Raimundo Correia:

Além nos ares, tremulamente,

Que visão branca das nuvens sai!

Luz entre as franças, fria e silente;

Assim nos ares, tremulamente,

Balão aceso subindo vai...

Há tantos olhos nela arroubados,
No magnetismo do seu fulgor!

Lua dos tristes e enamorados,

Golfão de cismas fascinador!

$(\ldots)$

Lunárias flores, ao feral lume,

- Caçoilas de ópio, de embriaguez -

Evaporaram letal perfume...

E os lençóis d'água, do feral lume

Se amortalhavam na lividez...

Fúlgida névoa vem-me ofuscante

De um pesadelo de luz encher,

E a tudo em roda, desde esse instante,

Da cor da lua começo a ver.

E erguem por vias enluaradas

Minhas sandálias chispas a flux...

Há pó de estrelas pelas estradas...

E por estradas enluaradas

Eu sigo às tontas, cego de luz...

Um luar amplo me inunda, e eu ando

Em visionária luz a nadar,

Por toda a parte, louco, arrastando

O largo manto do meu luar... (CORREIA, 1961 , p. 346 a 348)

Raimundo Correia está na "Despedida de Orfeu" explícita e implicitamente incorporado. Quase explicitamente está nas "papoulas cinerárias", que espelham estas "lunárias flores", e também nas "penumbras d'água", "lençóis d’água" amortalhados "na lividez". Explicitamente está no "golfo de lua", que refere os famosos versos "Lua dos tristes e enamorados, Golfão de cismas fascinador!". "Plenilúnio" é o exemplar máximo da lunaridade de Raimundo, e exprime maravilhosamente esse sentimento nas imagens de imersão do sujeito lírico no "golfo de lua" dum "mar de lua" e, em sentido inverso, na internalização da paisagem enluarada: "Um luar amplo me inunda...". Impregnados mutuamente, sujeito lírico e luar pleno se interpenetram a ponto de os limites entre um e outro se diluírem. A insânia que se apodera da voz poética resulta da fusão desse 
sujeito lírico com o luar. Dos versos emerge uma dimensão cinza-azulada em que a lógica do cotidiano fica abolida em benefício do que dita a luz lunar que a tudo alucina e penetra. É um tanto dessa atmosfera de luz líquida que a "Despedida de Orfeu" propõe-se a sugerir com seu "golfo de lua".

Implicitamente, Raimundo surge na "Despedida" na busca muriliana do sortilégio verbal, que a Raimundo permitiu escrever, no juízo de Manuel Bandeira, alguns dos versos mais misteriosamente belos da língua portuguesa. Em "Plenilúnio", dois exemplos desse poder de encantamento são a expressividade do advérbio "tremulamente" na primeira estrofe, que imprime movimento nos versos em que surge e no conjunto da estrofe; e a beleza misteriosa e sugestiva dos versos "E erguem por vias enluaradas/ Minhas sandálias chispas a flux... / Há pó de estrelas pelas estradas. " Na "Despedida", imagens e ritmos se encadeiam em busca do efeito encantatório indispensável à matéria poética e proveniente em parte da experiência da poesia lunar de Raimundo. A alma das coisas, espalhada por toda parte, e que a todas as coisas insufla vida, percepção, inteligência de si mesmas e das outras coisas do mesmo mundo aí está, em Raimundo e na "Despedida de Orfeu". A "orquestração da terra" de que nos fala Murilo é também o mundo concertado, a harmonia dos entes que se entressabem nessa inteligência recíproca a que Orfeu - e Raimundo - têm acesso. No Retratorelâmpago dedicado a Raimundo Correia, Murilo data e localiza sua precoce admiração pelo poeta ("Juiz de Fora 1913") e prossegue: "Com teu livro na mão, debruço-me à janela procurando distinguir, na cidade sem mar, bater aos pés de Vênus o coração das águas satisfeito". (1994, p. 1211). Note-se o quanto há de revelação órfica nesse pequeno relato de Murilo: é a imagem poética que do olhar do menino se espalha sobre a cidade, procurando descobrir nela o feérico (aqui expresso por imagens retiradas do soneto "Citera", de Raimundo) que a primeira visada não denunciava. Sobre Raimundo, Murilo continua, leitor atilado, artífice do próprio arquivo pessoal: "Vem-me o banzo, imensa, imensamente; retiro-me arrastando o largo manto do luar; mas, esperto, tomo nota desses adjetivos elegantes, desse metro flexível. Atingira o teu golfão (ou gólfão) de odes e sonetos." (1994, p. 1211). A lunaridade não é exclusiva de Raimundo; Alphonsus também é dos que a manejam:

\section{Ária do luar}

O luar, sonora barcarola, Aroma de argental caçoula, Azul, azul em fora...

Cauda de virgem lacrimosa, Sobre montanhas negras pousa, Da luz na quietação radiosa.

Como lençóis claros de neve, Que o sol filtrando em luz esteve, É transparente, é branco, é leve.

Eurritmia celestial das cores, Parece feito dos menores

E mais transcendentes odores.

Por essas noites, brancas telas, Cheias de esperanças de estrelas, O luar é o sonho das donzelas.

Tem cabalísticos poderes Como os olhares das mulheres:

Melancoliza e enerva os seres.

Afunda no ar o alvo cabelo, E brilha logo, algente e belo,

Em cada lago um sete-estrelo.

Cantos de amor, salmos de prece, Gemidos, tudo anda por esse

Olhar que Deus à terra desce.

Pela sua asa, no ar revolta, Ao coração do amante volta A Alma da amada aos beijos solta. Rola, sonora barcarola, 
Aroma de argental caçoula,

O luar, azul em fora, rola... (GUIMARAENS, 1960, p. 115-116)

Novamente se encontra a associação da luminosidade quase tátil do luar com a água - mais uma das "penumbras d'água" - na imagem do "alvo cabelo" do luar que "brilha logo, algente e belo" e produz "em cada lago um sete-estrelo": no elemento líquido mergulha e dele emite luz uma constelação. Mas esta luminosa melodia fina da lua se endereça a outro ponto: é ela que liga o céu à terra e permite o trânsito da alma da amada morta ao encontro do sujeito lírico. Nesse aquário de luz que o poema instaura, céu e terra se tocam e a canção ("sonora barcarola") é também a "asa" que transporta a alma da amada perdida até o amante exaurido de saudade e contemplação. "Jovem morta que me deste a vida" é o verso que, na "Despedida", se segue ao "terreno vago das estrelas". "Constelação frouxa da minha insônia" diz a "Despedida" sobre a "sombra de Eurídice". Há Alphonsus nessas imagens da amada morta muriliana. É o próprio Murilo quem diz na "Contemplação de Alphonsus":

Dorme Alphonsus no chão elementar,

Dos homens desligado que ele amou.

Aos seus versos polidos pelo ofício,

Patinados no tempo, nobres versos

Que geram em nós a lua e sua espuma,

O sete-estrelo geram, e o resplendor

Do céu noturno, a fantasmagoria

De trágicas imagens, e de acordes

Percutidos em címbalo e celesta,

Geram o mito maior, mito da morte

Mais uma vez nascido de mulher

Bem cedo extinta, cerrada magnólia

De véus sombrios, tenra Beatriz

Que, inda o livro da vida soletrando,

Indica à poesia a sua clausura

Em que tão fundo a alma se contempla

Quando abaulada carruagem a leva

Aos solavancos, na penumbra oculta

De soturnos veludos e debruns,

Aos seus versos polidos pelo ofício
Responde a natureza com o silêncio E os lilases ao longo do esqueleto. (1994, p. 491)

O mito da "noiva morta" servido pelo luar, e o "mito maior, mito da morte" estão lá, na "Despedida de Orfeu", seja como a "jovem morta que me deste a vida", seja no "longo texto de mil metáforas". A imagem da "cerrada magnólia de véus sombrios" é usada por Murilo para designar Constança, a que veio a ser para Alphonsus o que Beatriz fora para Dante. Essa imagem informa que as "magnólias da manhã" da "Despedida" são também referência à "jovem morta" e à "constelação frouxa" do mesmo texto. Nesse jogo de relações, tem importância esclarecedora o depoimento de Murilo Mendes no "Retrato-Relâmpago" dedicado a Castro Alves:

A poesia 'O visionário', do meu livro As metamorfoses, pela temática, pelo ritmo, pelas imagens, descende diretamente de Castro Alves. A 'magnólia cálida' do mesmo livro e a 'magnólia móbile' de um texto recentíssimo filiam-se à sua famosa 'camélia pálida'. (1994, p. 1215)

Este modo de fazer com que os textos se leiam uns aos outros e uns nos outros como o desenvolvido neste trabalho se baseia nos procedimentos do próprio Murilo Mendes. É ele quem revela que os textos se refletem uns nos outros pelo tema, pelo ritmo, pela dicção; uma palavra ou uma imagem podem conter toda uma poética alheia que se pode incorporar, enfeixar à própria. A "camélia pálida" está no poema "Mocidade e Morte": "Vem! formosa mulher - camélia pálida,/ Que banharam de pranto as alvoradas./ Minh'alma é a borboleta, que espaneja/ O pó das asas lúcidas, douradas..." (ALVES, 1986, p. 88) Não há por que não ligar as duas magnólias de ascendência castro-alvina às "magnólias da manhã" da "Despedida de Orfeu", o que equivale a dizer que também Castro Alves adere ao feixe de vozes que é a voz de Orfeu. Aliás, a "camélia" de Castro Alves é também ela uma flor da manhã, molhada pelo orvalho das alvoradas.

É proveitosa a investigação mais detida dessas flores verbais. A "magnólia cálida" está no poema "Anamorfose", de As metamorfoses: 
Procurei-te Eleonora

Como um simples humano procura a árvore,

Mas que espanto e surpresa!

Tive de cobrir o rosto com a cinza do arranha-céu

E interrogar o hieroglifo da esfinge.

Magnólia cálida

Noite da aurora

Eleonora

Assim fiquei à tua espera

Em pé no monumento de areia

- Meu próprio coração absurdo.

O vento atirava largos véus

Nas constelações de perfil.

Surgiste

Ai de mim!

Dama da Inquisição

Envolta numa camisola de nuvens

Anunciando meu exílio

Antes que os cães da tua febre

Devorem meu corpo

Ao primeiro aceno da manhã. (MENDES, 1994, p. 369)

A anamorfose é a deformação calculada, é a metamorfose obediente a parâmetros que permitem até reencontrar a imagem inicial, desde que se recorra ao ângulo apropriado. A "camélia pálida" de Castro Alves é metáfora de "formosa mulher". E metáfora que se desdobra em outra, a da alma do sujeito lírico transformada em "borboleta". Há um delicado conteúdo erótico no pouso implícito de uma metáfora sobre a outra. A "magnólia cálida" de Murilo, também metáfora também aplicada a mulher, faz supor erotismo e aconchego, mas essa imagem se anamorfoseia na "Noite da aurora" - a disposição espacial dos dois versos enfatiza esse movimento de transformação da flor quente (ou sagaz e experiente, já que "cálida" também pode ter esses sentidos) em amanhecer sem luz. A mulher que se supôs ente vegetal se revela ligada ao arranha-céu e se mostra esfinge que emite hieroglifo a decifrar. Destroçando as expectativas de um "coração absurdo" (também "monumento de areia"), povoado de sentimentos sem sensatez nem consistência, Eleonora é "Dama da Inquisição" e anuncia o exílio e a morte do sujeito lírico. Essa mulher surge numa "camisola de nuvens" - há um traço de erotismo onírico nessa imagem - e, como Ártemis ultrajada, envia os cães de sua febre para devorar o corpo do poeta - proviria dessa febre a calidez dessa magnólia? A cena toda, de confronto e hostilidade, retoma a alvorada castro-alvina ("ao primeiro aceno da manhã") com sabor surrealista e apocalíptico na atmosfera de sonho que instaura, no conjunto visualmente forte que instala. Eleonora integra a categoria das górgones murilianas, mulheres torcionárias, de quem o incauto venerador se aproxima em busca de ternura e prazer e por quem acaba submetido à ação do serrote e da torquês. Estão em $A$ idade do serrote essas noções sobre mulheres implacáveis.

Já a "magnólia móbile" é imagem que surge no poema "Grafito na pedra de minha mãe", da primeira parte de Convergência, livro publicado em 1970:

A pedra abre os olhos mansos de colomba.

Morte polêmica

Morte que separa homem \& sombra rosa \& espinho

Catapultou-me da esfera do teu ventre Para este território ásperoanguloso Onde soou no espaço

A primeira ruptura: tempo subtraído-te, História em mito permutada

Eletronicamente.

Bela / jovem / magnética

Talhada para canto \& clavicímbalo

Te eclipsas no limiar do século

Que cedo iria me absorver

No seu contexto polêmico.

Extraindo-te de mim 


Fechando-te magnólia móbile
selenocêntrica
Elisa Valentina minha filha unigênita
Tornaste-me
Espiritado esdrúxulo;
Geraste
Minha cosmogonia.
Juiz de Fora 1964 (1994, p. 630)

É do mundo mineral animado por alma de pássaro que o poema parte para tratar da "morte polêmica", a da própria mãe, que, em 1902, morreu de parto. Note-se que Murilo nasceu em 1901 e que, apesar de o poema sugerir que a perda da mãe se deu quando Murilo nasceu (releia-se a estrofe que se inicia com a "morte polêmica"), não foi o que literalmente ocorreu. Isso é revelador do modo como o poeta confeccionava sua mitologia pessoal e construía os personagens de si mesmo a oferecer em sua obra. A "jovem morta que me deste a vida" da "Despedida de Orfeu" é também Elisa Valentina, confundindo-se com Eurídice, "constelação frouxa de minha insônia", - em trecho de A idade do serrote, Murilo escreve: "Minha mãe, afeiçoada ao canto e ao piano, morre de parto aos vinte e oito anos. Torna-se constelação." (1994, p. 896) - como geradora do poeta e do canto poético. Elisa Valentina, a personagem, o mito, é "filha unigênita" de Murilo e gerou a "cosmogonia" do poeta, seu modo de ser "espiritado" e "esdrúxulo". Com a morte, a bela mãe musical, extraída do poeta, convertida em filha, fechou-se na "magnólia móbile" e "selenocêntrica", que ecoa aquela "cerrada magnólia de véus sombrios" impregnada de luz lunar alphonsina. A essa última magnólia, não se deve esquecer, está ligada a geração do "mito maior, mito da morte" "nascido de mulher bem cedo extinta". A Elisa Valentina do "Grafito" é "móbile" em parte porque Murilo havia optado por uma poética de construção textual ostensivamente moderna, na altura da composição dos poemas de Convergência, e a disposição gráfica do texto sobre o papel, o apelo a símbolos como "\&" e "/", o vocabulário da técnica ("catapultou-me", "móbile", "eletronicamente") são índices dessa tecnologização poética. Elisa Valentina é "móbile" também porque personagem em movimento, figura trágica da realidade biográfica transposta para a realidade literária, de onde, geradora do mito da amada morta, se faz Eurídice, Beatriz, Laura, Constança, Elisa novamente... O próprio poeta, assim, é personagem de si mesmo. É inegável que fazer da própria mãe jovem, bela e musical a magnóliaamada-morta seria tema para digressões freudianas sobre desejo e repressão do desejo. A próxima magnólia muriliana que se vai ler só faz aumentar a vontade de convocar a psicanálise, mas neste trabalho não há como desenvolver esse veio analítico:

\section{A magnólia}

1915. De uma janela da casa paterna distingo no pomar a magnoleira, magnífica de largas folhas e flores. Ninguém ignora que existem variedades menores de magnoleiras, mas esta, penso, é a Magnolia grandiflora de Lineu: indicam-no o espaço que ocupa, a dimensão espetacular de suas flores em copa.

Refiro-a imediatamente a uma mulher: na série das "correspondências" a magnólia seria a forma vegetal da minha prima Abigail, por exemplo. Observem a sutileza desta proposta: a magnólia aparenta-se a Abigail, não Abigail à magnólia. Imagino também o paraíso terrestre sem Adão e Eva, sob a figura da magnólia.

A magnólia ataca-me os sentidos, não só pela sua forma generosa, ainda pelo seu aroma esdrúxulo extraído ao Oriente. Certo que a magnoleira foi transplantada da Ásia e da América; batizou-a com este nome o próprio Lineu, em homenagem ao botânico Pierre Magnol, seu classificador.

Descubro outra magnoleira malencônica no parque do colégio. Tempo absurdo de verão, estoura 0 sol, a magnoleira perturba-se, adivinhando tanajuras lá embaixo; ameaça fechar suas flores. Quanto a mim, nutro-me da sua forma aberta, do seu aroma especioso, dos seus peitos, da sua cor entre branco e creme. 
Devido à magnoleira gazeio aulas, mormente a de matemática: uma flor de magnólia vale bem uma equação.

A magnoleira treme agora da cabeça aos pés. Quem sabe está narrando sua infância ao vento? (MENDES, 1972, p. 54-55)

Esse texto pertence a Poliedro, livro publicado em 1972. Aí está a história de um mito pessoal contada pelo próprio poeta. Da viva experiência dos sentidos, a magnoleira se transmuda em metáfora de mulher, em possibilidade de retorno a um Éden "sem Adão e Eva" (sem a queda?), em ente a um só tempo mulher e vegetal (é mulher ou árvore a "magnoleira malencônica" do colégio? É metamorfose em processo...). N' A idade do serrote, Murilo informa: "Os peitos de Abigail: arrogantes, torreando no corpo. " (1994, p. 951). E a magnoleira do último parágrafo, onde-quando está? É a mesma de 1915? É Abigail? De onde é contemplada? É e não é a mesma, pois o poeta contempla a magnólia da sua memória, que se projeta com todas as suas formas - cheiro, cor, peitos, flores abertas e fechadas, luz e sombra - sobre as magnólias anteriores.

É didática a forma como Murilo apresenta a constituição do mito. Carlo Diano elaborou as categorias de "evento" e "forma" para analisar o pensamento grego. Posteriormente, passou a considerá-las categorias aplicáveis a qualquer civilização. O contemplar a magnólia naquele ondequando apontado no primeiro parágrafo do texto propicia o evento:

Che qualcosa accada, non basta a farne un evento: perché sia un evento è necessario que codesto accadere io lo senta come un accadere per me. E però, se ogni evento si presenta alla coscienza come un accadimento, non ogni accadimento è un evento. (...) Di evento dunque non si può parlare se non in rapporto a un determinato soggetto e dall'ambito stesso di questo soggetto. E, poiché è in tale rapporto e da tale ambito che l'accadimento, venendo costituito in evento, si svela anche alla coscienza come accadimento, non solo accadimenti possono essere sentiti come eventi, ma anche quelle che noi chiamiamo le cose, nell'atto in cui l'uomo ne avverte l'esistenza come qualcosa che sia per lui e non per se stessa. (DIANO, 1973, p. 7-8)
O evento é aquilo que é desvelado num aquiagora que se recorta do infinito amorfo anterior ao tempo e ao espaço; é a "pura esistenzialità puntualizzata" num instante em que se percebe que o percebido provém de uma periferia infinita e até então amorfa, e dela emerge porque a consciência o captura. Essa relação é sentida e não pensada, ensina Diano. A primeira definição dessa periferia infinita é o ápeiron de Anaximandro de Mileto, o sem-limite primordial e universal do qual a percepção vai fazendo emergir a realidade. Mas para que esse evento recortado possa ser preservado, é necessário não apenas percebê-lo, mas também conformá-lo:

La reazione dell'uomo a questo emergere del tempo ed aprirsi dello spazio creatigli dentro e d'intorno dall'evento, è di dare ad essi una struttura e chiudendoli dare forma all'evento. Ciò che differenzia le civiltà umane, come le singole vite, è la diversa chiusura che in esse vien data allo spazio e al tempo dell'evento, e la storia dell'umanità, come la storia de ciascuno di noi, è la storia di queste chiusure. Tempi sacri, luoghi sacri, tabù, riti e miti non sono che chiusure d'eventi. (...) La più semplice forma de chiusura é il nome. Specificando la potenza che si rivela nell'evento, il nome ne supera l'infinità, rendendo così possibile all'uomo di liberarsi dal thambos e di dare una direzione alla propria azione. Ma questo medesimo nome, che dà forma all'evento, permette anche di riprodurlo. (...) Lo stesso vale per il mito, che non è se non uno sviluppo del nome, e che, come il nome, dando forma a un evento, lo chiude e ne permette la ripetizione in un rito. (DIANO, 1973, p. 12-13)

Há um alumbramento da consciência que permeia o aqui-agora em que o evento é fechado em nome ou mito, e o fechamento - individual ou civilizacionalmente realizado - permite ao homem liberar-se da imediatez física do que já se transformou em ali-então dessa epifania. O evento passa a ser a partir daí reproduzível pelo nome ou pelo mito - que sempre remetem ao ali-então original que simbolizam, criando uma relação especular entre o que são em sua materialidade e o ali-então a que se referem. É por isso que se pode dizer do mito que está na origem dos tempos e em todos os tempos. É o que é e reflete o alientão que fechou. E é por isso que, rigorosamente, é indissociável do rito que reedita pela dramatização aquele evento aprisionado. Sem o rito, informa Diano, o mito é fábula. Em casos como o de Murilo Mendes o rito está presente numa constante dramatização - no 
sentido teatral (litúrgico?) do termo - da matéria poética, como é o caso da "Despedida de Orfeu", que ostenta marcas de um monólogo em performance elegíaca e das incontáveis ocorrências, explícitas e implícitas, da palavra-gesto "eis" em seus textos. O mito, em Murilo, é nostalgia da origem, do evento alumbrante que o gerou. E o rito com que se deveria sempre conjugar muitas vezes é uma ausência presente, o que o incorpora ao texto. O poema-poética O rito geral, que será lido em breve, é o emissor perene da presença dessa ausência.

Ora, a magnólia muriliana se elevou à categoria de mito num nítido processo de fechamento de um evento. O texto de Poliedro mostra esse recortar-se da magnólia do quintal paterno, sentida como existente para o sujeito que a percebia naquele ali-então. Esse olhar individual, exercido por um poeta, é buscadamente arcaico, adâmico; mas as palavras há muito não são edênicas - trazem incrustada em si a própria história delas. Por isso, fechar um evento num mito significa também, em tempos pós-arcaicos, adicionar ao percebido como evento o que se sabe que outros fechamentos ao longo da história fixaram. Por isso, a magnólia de Murilo é o mito que ele criou, o alientão do quintal da casa paterna, adicionado da "camélia pálida" de Castro Alves e de outros fechamentos, escaváveis em magnólias e camélias.

Esse modo mítico de lidar com a matéria da vida é constantemente referido na obra de Murilo Mendes. O poema em prosa "O servo de Deus", de O sinal de Deus, é explícito: "Quando vi passar o cometa de Halley, em 1910, tive a revelação fulminante da poesia: acreditei que o cometa vinha PARA MIM." (1994, p. 761; maiúsculas do original). Aí estão o thambos, o evento, a epifania percebida e transmudada em mito.

Por ter conformado o evento numa forma simbólica verbal, o homem adquiriu a prerrogativa de transportar mentalmente um ali-então (que, não se deve esquecer, mantém uma relação original com o todo ilimitado do qual se destacou), que passa a ser elaborado e reelaborado pelo uso pessoal e social no qual desenvolve suas possibilidades de visão retrospectiva e prospectiva. Nesse processo, o trabalho intelectual de compreensão foi precedido de um trabalho percepcional capaz de desentranhar os fenômenos e coisas da indefinição periférica e atribuirIhes portabilidade espiritual pela simbolização - e deve-se levar em consideração que na execução desse trabalho percepcional houve a intermediação da sensibilidade humana, que nunca é neutra, ou seja, a percepção inicial dos acontecimentos que os elevou à categoria de eventos já foi ação da humanidade sobre o mundo, pois viu em determinados acontecimentos uma finalidade específica que não viu em outros. Ora, os eventos convertidos em metáforas que os transportavam acabaram por ser tomados por elas, pois elas é que circulavam no mundo mental e social dos homens. Há assim um ciclo que parte da percepção dos dados do mundo para a simbolização que permite sua interiorização e um percurso de retorno em direção à intelecção do mundo.

É nesse ciclo que se realizam as imagens de Murilo Mendes e seus companheiros de poesia: são passíveis de desvendamento arqueológico, de mapeamento na obra própria e alheia, de investigação retrospectiva e prospectiva. Considere-se novamente o caso das magnólias: são remetidas a Castro Alves pelo próprio Murilo, que as colhe para as replantar em "Anamorfose", na "Contemplação de Alphonsus", na "Despedida de Orfeu", no "Grafito na pedra de minha mãe", no texto "A magnólia".

Imagens poéticas alcançam o estatuto de mitopoemas, frutos do fechamento dos eventos em dadas formas linguísticas que são seres e forças substanciais e que conferiram a esses eventos portabilidade mental. Em sua origem está a relação com o evento capturado num ali-então - e sua reconvocação frequente em poemas é nostalgia e reafirmação desse vínculo primordial; na modernidade também se pode pensar que seja a consciência da perda irremediável desse mesmo vínculo. Sua recolha em poemas alheios e sua disseminação em poemas próprios decorrem do arquivar cuidadoso de imagens numa memória pessoal que atua como fonte ativa de formas e dicções quando o elaborar poético busca conformar-se em verbo. Elabora-se assim uma trama entretecida de pessoalidade e de alteridades, e a voz poética que se alça é a um só tempo voz própria e voz 
pública - e os limites entre uma instância e outro não se podem traçar com precisão. Tal é o rito inerente ao fazer poético, em que a experiência do homem é a da humanidade e a experiência da humanidade é a do homem:

\section{0 rito geral}

Guardião dos sonhos, levantei a aurora,

Advertindo os homens do trabalho inútil.

Tangia os sinos do universo-igreja,

Convocando formas e elementos

Para o ofício geral da poesia.

Vieram a mim os peixes das águas primitivas,

Vieram as enormes borboletas-fadas

Que cobriam de azul o abismo vazio.

Vieram as inspiradoras dos poetas desde o início, Veio a dália gigante de mil braços,

Veio o Filho do homem dançando sobre as ondas.

Eu dialoguei com eles,

Aprendi a história de todos

E todos aprenderam minha história

Que levaram para o outro lado da terra,

Para o fundo do mar e o céu.

Mundo público,

Eu te conservo pela poesia pessoal. (MENDES, 1994, p.330-331)

"O ofício geral da poesia" é, em sua essência, etimologicamente religioso, pois restabelece os liames entre os entes todos, suas histórias individuais e as dimensões invisíveis que mantêm as correspondências universais entre eles. É convocando os entes e ouvindo e contando narrativas que se realiza a liturgia poética que faz o homem integrar-se à humanidade, o pessoal amalgamar-se ao público, o público efetivar-se no pessoal. São as imagens que o sujeito lírico pastoreia que transportam em si o cerne das narrativas que se trocam no ofício da poesia. Ser poeta é, pois, ser pastor de imagens, próprias e alheias; é ser mediador do fluxo constante do coletivo ao individual, do individual ao coletivo e manipulador do material da memória no trânsito do pessoal ao público, do público ao pessoal. A este Orfeu, na modernidade, parece restar o papel de "cripto-vivente", constata Murilo Mendes. Se considerarmos, com Agamben, que "tendo se despedaçado a tradição, o homem não consegue mais encontrar entre passado e futuro o espaço do presente e se perde no tempo linear da história" (2012, p. 179), à poesia - como leitura incorporada, como escrita também a partir das memórias de leituras - resta participar dessa dilaceração ("Bacantes que destruís o que vos dei.") entre o que foi e o que é e dessa trágica incapacidade de conciliar tempos.

\section{Referências}

AGAMBEN, Giorgio. A linguagem e a morte. Um seminário sobre o lugar da negatividade. Belo Horizonte: Editora UFMG, 2006.

O homem sem conteúdo. Belo Horizonte: Autêntica, 2012.

ALVES, Castro. Obra completa. Rio de Janeiro: Nova Aguilar, 1986.

BARCA, Pedro Calderón de la. 25aa ed. La vida es sueño. Madrid: Cátedra, 1998.

CORREIA, Raimundo. Poesia completa e prosa. Rio de Janeiro: Nova Aguilar, 1961.

DIANO, Carlo. Studi e saggi di filosofia antica. Padova: Editrice Antenore, 1973.

GUIMARAENS, Alphonsus de. Obra completa. Rio de Janeiro: Nova Aguilar, 1960.

MENDES, Murilo. Poliedro. Rio de Janeiro: José Olympio, 1972.

.Poesia completa e prosa, Rio de Janeiro: Nova Aguilar, 1994.

MIRANDA, Francisco de Sá de. Obras completas. $2^{\underline{a}}$ ed. Lisboa, Sá da Costa: 1942. 2 v.

PEREIRA, Maria Helena da Rocha (Org. e trad.). Hélade. Antologia da cultura grega. 9a ed. Porto: ASA Editores, 2003.

PASCAL, Blaise. Pensamentos. $2^{a}$ ed. São Paulo: Martins Fontes, 2005.

RIEDWEG, Christoph. "Orfeo”. In: SETTIS, Salvatore (Org.). I greci. Storia, cultura, Arte, società. Torino: Einaudi, 1996. Tomo 2-V1: Formazione. 


\section{COMO CITAR ESSE ARTIGO}

INFANTE, Ulisses. Murilo Mendes incorpora a poesia. Signo, Santa Cruz do Sul, v. 41, n. 72, out. 2016 . ISSN 1982-2014. Disponível em: <https://online.unisc.br/seer/index.php/signo/article/view/7103>. Acesso em: doi: http: //dx.doi.org/10.17058/signo.v41i72.7103. 